\title{
RECENT RESEARCH ON DOWNY MILDEW RESISTANCE USEFUL FOR BREEDING INDUSTRIAL- USE SUNFLOWERS
}

\author{
Vear, F. ${ }^{*}$, Serre, F., Roche, S., Walser, P., Tourvieille de Labrouhe, D.
}

INRA, UMR “Amélioration et Santé des Plantes", Domaine de Crouelle, 234, Ave du Brezet, 63000 Clermont-Ferrand, France

Received: October 10, 2006 Accepted: May 15, 2007

SUMMARY

For sunflowers to be a profitable industrial-use crop, input costs must be as low as possible. Genetic resistance is therefore essential to control diseases without any spraying or seed treatment procedures. In France, Downy mildew is one of the most potentially important diseases. So far, complete, major gene resistance ( $P l$ genes) has been used successfully, but with the appearance of seven new races since 2000, research on more durable resistance has been undertaken. Since 2003, methodologies for large-scale trials have been developed to study field reaction to Downy mildew attacks on genotypes which do not have $P l$ genes effective against the predominant races present. It has been shown that significant levels of partial resistance exist in cultivated sunflower lines ( $15 \%$ infection when susceptibles show $80-90 \%$ infection). This resistance appears independent of race (at least 710 and 703). Heredity is under additive control and the behaviour of hybrids can be quite well predicted from inbred lines. Present and future research programmes are discussed and suggestions are made for the use of partial resistance in breeding programmes.

Key words: sunflower, Downy mildew resistance, $P l$ genes, research for durable resistance, partial resistance

\section{INTRODUCTION}

For sunflower to be a profitable source of raw materials for industrial transformation or bio-fuels, this crop must compete with other sources of equivalent composition. Production costs must therefore be reduced as far as possible. It may be that 3-way hybrids will become of increased interest as varietal structures, and crop management may be limited to sowing and harvest. For disease resistance, the variety must defend itself, with no spraying or seed dressing. Thus genetic resistance is essential. For the breeder to be able to concentrate on increasing yield under low

* Corresponding author: Phone: 33.4.73.62.43.06; Fax: 33.4.73.62.44.353;

e-mail: vear@clermont.inra.fr 
input conditions, it is important that he does not have to spend too much money or effort on breeding for disease resistance. Any work he does will have to be durable.

In France the most important or potentially most important diseases are Downy mildew (Plasmopara halstedii), white rot (Sclerotinia sclerotiorum), Phomopsis (Diaporthe helianthi) and Phoma (Phoma macdonaldii). Phoma is a quite new problem and studies still concern yield loss and epidemiology. Phomopsis attack has lessened in recent years, probably because breeders have developed varieties with good resistance which appears to be of the partial type, without the appearance of pathogen races. Research on, and breeding for, Sclerotinia resistance is certainly still necessary but since this resistance is partial and no interactions with isolates have been found (Vear et al., 2004), it can be considered that the increases in resistance that have been obtained will not be lost in the future. In contrast, in recent years, there has been a continuous chase after new resistances to Downy mildew. This resistance, controlled by major genes, denoted $P l$, is complete but race specific. Since 2000, 7 new $P$. halstedii races have been reported (Moinard et al., 2006), meaning that the reaction of many varieties that were registered as resistant (or re-registered after introduction of new $P l$ genes) varies according to where they are grown. Breeders have to spend much time back crossing their best inbred lines to introduce new $P l$ genes (Vear, 2004).

New $P l$ genes do exist. So far, $P l$ genes have been found to be grouped in clusters, each "gene" (taken in the Mendelian inheritance sense) giving resistance to one or a few races. Three clusters have already been published (Mouzeyar et al., 1995; Bert et al., 2001; Dussle et al., 2004) and studies in progress suggest that at least two more exist. In addition, studies on introgressions and wild Helianthus annuus by both USDA and INRA have shown that $P l$ genes are not rare in wild annual Helianthus species (T.Gulya, H.Serieys, personal communications). It might be possible to continue to breed sunflower varieties resistant to the main races of Downy mildew with genes from these sources, but if there is no reflection on their use, it is likely to lead to a waste of time and money (Tourvieille, 2004)

Research for durable resistance to sunflower is recent, the best methods are not yet proven. Taking into consideration all the work on model and crop species and the similarities in resistance gene structures between species, it might be possible to identify major resistance gene structures that are more durable than others. Already it is known that the cluster containing Pl6, giving very complete resistance but which has already been overcome by races $304,314 \ldots$, is of the TIR-NBS-LRR type (Bouzidi et al., 2001), whereas the cluster containing Pl8, which has not yet been overcome but gives "cotyledon limited susceptibility", is an NBS-LRR-CC (Radwan et al., 2002). However, application of this idea does not appear to be an immediate prospective.

The alternative is resistance of sunflower which does not depend on host/pathogen interaction and recognition, so that selection pressure on the pathogen population is much reduced. This type of resistance, usually partial, is what we know for 
Sclerotinia. If resistance levels are sufficient to avoid yield loss it could be used alone. This could be possible for Downy mildew attack, which occurs on young plants when there can be compensation by healthy plants, in comparison with Sclerotinia capitulum rot which appears just before harvest with no possibility of compensation. However, partial resistance could also be combined with $P l$ genes so that, if spores or mycelium of a new pathotype formed, their multiplication would be so limited that a new race would not develop.

Partial resistance to Downy mildew has been studied in France since 2003, in a collaboration programme between INRA, CETIOM and breeders (Oléosem). First results were presented at Fargo (Tourvieille et al., 2004). This paper presents the research carried out in the last 3 years, particularly concerning large-scale trials, and discusses programmes in progress and possible use of this type of resistance in breeding.

\section{MATERIALS AND METHODS}

\section{Sunflower genotypes}

1. Genetic resources: To determine the variability and levels of resistance available in cultivated sunflower, in 2004 and 2005, 820 inbred lines covering all the origins in the collections at INRA, Clermont-Ferrand and some at Montpellier, 73 open-pollinated varieties or populations and 59 lines representing introgressions from wild Helianthus species, were studied in trials at Clermont-Ferrand. The best lines were observed in another two-year trial (2005 and 2006), conducted either at Clermont Ferrand or in multi-location trials in collaboration with French sunflower breeders.

2. Hybrids: From first results in 2003 and 2004, factorial crosses between 6 females [FRIGA, FU, GU, GX(2006), HA89(2005), H52(2005), IR(2006), SL72] and 5 or 6 restorers [83HR4, 90R18, PAZ2(2006), PR56, PSU7, PUR2(2006), RHA266(2005)] were used to produce hybrids representing the whole range of resistance/susceptibility observed for inbred lines. These hybrids were observed in trials in 2005 and 2006.

3. Checks: inbred lines were chosen from first results in 2003 and confirmed in following years: good resistance B-line FU, restorer PR56, poor resistance: B-line GB, restorer: PSU7. These checks were placed in all trials to permit comparison between years and locations.

\section{Infection Methods and Observations}

1. Sowing and Irrigation. Untreated seed were sown with a normal trials/ breeding nursery drill at double density (100-120,000/ha) at the normal sowing date for sunflower (late April at Clermont-Ferrand), with 2-row plots of 50-60 plants. 
Eight to 10 days after sowing, when radicle length was $2-3 \mathrm{~cm}$, complete-cover sprinkler irrigation provided at least $60 \mathrm{~mm}$ of water. For the following 2-3 weeks further irrigations were made if there was no rainfall (10-20 mm/week).

Trials were made in fields naturally infected with Downy mildew; when necessary, to homogenise infection, fresh zoospores from infected plants were added to irrigation water. Downy mildew race was checked by sowing differential lines next to the trials.

2. Observations. Three to 4 weeks after sowing (cotyledon stage), the number of plants emerged in each plot was counted (including those showing symptoms of damping off).

Two to 3 weeks later (2-3 pairs of leaves), the number of healthy plants per plot were counted (rather than the number of diseased plants since some of these had already withered).

Percentage infection was then calculated from (100-\% healthy plants).

Immediately after verification of counts, the trials were rotavated or ploughed and maize, barley or a forage grass were cropped the same year. At the end of the programme, the fields were disinfected if required.

\section{RESULTS}

\section{Checks}

Infection levels varied between years. The means infection levels for the four check inbreds at Clermont-Ferrand are presented in Table 1. The relative reactions of the four lines were quite stable and it is considered that lines with significantly less infection than the mean of these checks present useful levels of partial resistance.

Table 1: Percentage Downy mildew attack in 2003, 2004, 2005 and 2006 on the 4 inbred sunflower lines used as checks for trials since 2004

\begin{tabular}{lcccc}
\hline Line & 2003 & 2004 & 2005 & 2006 \\
\hline PR56 & $18.16 \% \pm 6.24$ & $31.72 \pm 4.37$ & $23.38 \pm 3.95$ & $18.97 \pm 2.54$ \\
FU & $28.98 \% \pm 5.09$ & $61.48 \pm 4.84$ & $62.23 \pm 5.55$ & $31.54 \pm 4.37$ \\
GB & $58.75 \% \pm 10.85$ & $88.21 \pm 1.87$ & $81.09 \pm 2.53$ & $73.89 \pm 6.39$ \\
PSU7 & $73.50 \% \pm 9.48$ & $90.84 \pm 2.47$ & $86.23 \pm 3.30$ & $74.77 \pm 5.66$ \\
\hline
\end{tabular}

\section{Genetic resources}

Figure 1 presents the complete range of inbred lines, compared with the checks. About one third of the genotypes showed some resistance and 5\% (43 inbred lines, 1 population and 1 introgression source) have been confirmed as significantly more resistant than the check mean over two years and, for the 20042005 group, in multi-location trials. Table 2 presents an overall analysis of this trial in four locations, one trial with race 703 and three with race 710 . Results in the dif- 
ferent locations were all highly significantly correlated ( $r=0.45$ to 0.59 ), in spite of the differences in level of attack. Reaction does not appear to vary with race.

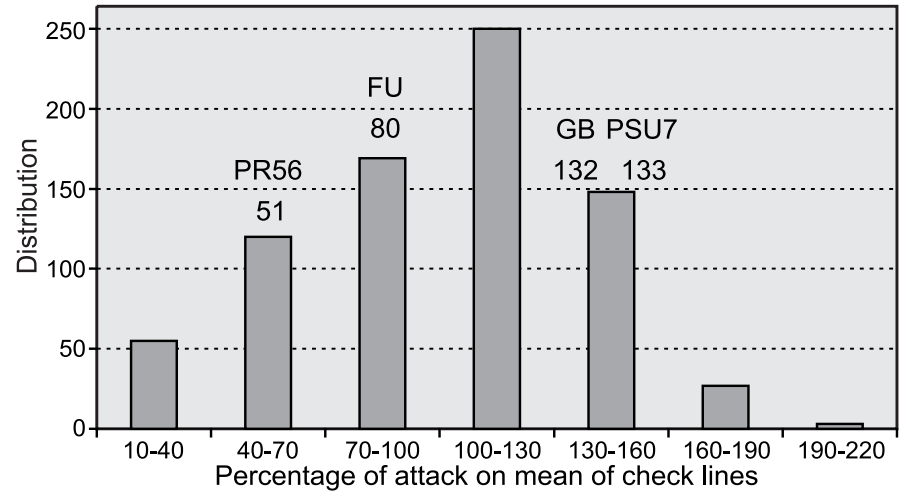

Figure 1: Distribution of Downy mildew attack on nearly 1000 cultivated sunflower genotypes compared with the mean of the 4 check inbred lines indicated

Origins of resistance appear to be quite diverse, among them:

- very old lines maintained in our collection since 1970 (e.g. line from Romanian genic hybrid HS53),

- old inbreds dating from 1980-90 (e.g. INRA: PAH3, PB3, PR56, GX (from BU 1507), USDA: HA 60, HA 113, Canada: CM304, Russia: MO60, MO502, VIR1634),

- recent breeding lines (e.g. INRA: BB, BT, IR (from Impira), FU, USDA: RHA 387, RHA 418, HAR8 ).

\section{Inheritance}

In 2005, study of 30 hybrids ( 6 females $\times 5$ restorers) in 4 locations showed highly significant parental effects $\left(\mathrm{F}_{\mathrm{f}}: 5.29^{* *}, \mathrm{~F}_{\mathrm{m}}: 12.18^{* *}\right)$ and no significant interaction $\left(F_{i}: 1.96\right)$. Infections levels varied from $30 \%(F U \times 90 R 18)$ and $32 \%$ $(F U \times$ PR56) to $83 \%($ HA89 $\times$ PSU7 and SL72 $\times$ PSU7) for a mean attack of $65 \%$.

For 2006 , the results for a $6 \mathrm{~F} \times 6 \mathrm{R}$ factorial at Clermont-Ferrand are presented in Table 3. Infection level for the two best hybrids in 2005 was slightly lower $($ FU $\times 90$ R18 : $21 \%$, FU $\times$ PR56 : 22\%) while it was higher for the most susceptible genotypes (SL72 $\times$ PSU7 : $91 \%$ ), for a mean of $47 \%$.

This greater difference was probably because the results are for a single trial. Compared with 2005, the main difference came from the introduction of IR, a female line which gave hybrids showing infection levels of only 8 to $32 \%$. Parental effects were very highly significant, and there was no significant female-restorer interaction. It can be concluded from the two-year results that heredity is under additive control.

Correlations between reactions of inbred lines (Table 4) and the means of their hybrids were significant both for females $\left(r=0.916^{* *}\right)$ and restorers $\left(r=0.817,{ }^{*}\right)$. It 
Table 2: Percentage attack by Downy mildew in 4 locations in 2005. Check $=(\mathrm{GB}+$ FU+PSU7 + PR56)/4. (Check mean: 52.5\%). T1-T4 : Trial 1 to Trial 4, with Downy mildew race identified.

\begin{tabular}{|c|c|c|c|c|c|c|c|}
\hline \multirow{2}{*}{ Inbred line } & \multirow{2}{*}{$\begin{array}{c}\text { Mean \% } \\
\text { attack }\end{array}$} & \multirow{2}{*}{$\begin{array}{c}\% \text { check } \\
\text { mean }\end{array}$} & \multirow{2}{*}{$\begin{array}{l}\text { Sig. dif } \\
\text { check }\end{array}$} & T1 & T2 & T3 & T4 \\
\hline & & & & 710 & 710 & 703 & 710 \\
\hline GB & 62.29 & 118.70 & NS & 96.66 & 27.81 & 75.64 & 49.04 \\
\hline FU & 35.40 & 67.46 & NS & 73.97 & 18.52 & 36.12 & 12.98 \\
\hline PSU7 & 77.60 & 147.89 & SUP & 100.00 & 43.53 & 74.28 & 92.61 \\
\hline PR56 & 34.61 & 65.96 & NS & 42.66 & 39.88 & 32.01 & 23.89 \\
\hline 83HR4 & 58.73 & 111.91 & NS & 93.22 & 28.13 & 75.26 & 38.29 \\
\hline 90R18 & 28.95 & 55.16 & INF & 75.62 & 5.49 & 14.25 & 20.43 \\
\hline AR 1465 & 37.41 & 71.28 & NS & 53.00 & 25.49 & 27.34 & 43.79 \\
\hline BB & 26.19 & 49.90 & INF & 63.33 & 9.10 & 15.23 & 17.09 \\
\hline BT & 30.02 & 57.20 & INF & 63.06 & 22.32 & 17.67 & 17.02 \\
\hline BU 928 & 51.40 & 97.96 & NS & 93.90 & 60.67 & 36.27 & 14.77 \\
\hline HA89 & 45.02 & 85.79 & NS & 89.88 & 32.00 & 25.38 & 32.81 \\
\hline CM617 × CM620 & 24.11 & 45.95 & INF & 51.18 & 8.75 & 26.47 & 10.05 \\
\hline A1786 & 19.94 & 37.99 & INF & 50.53 & 3.57 & 14.56 & 11.09 \\
\hline DIV.2. & 22.99 & 43.81 & INF & 57.52 & 0.00 & 23.35 & 11.09 \\
\hline DSCL114 & 13.84 & 26.37 & INF & 39.30 & 9.20 & 1.19 & 5.66 \\
\hline E 474 & 31.60 & 60.22 & INF & 62.99 & 10.36 & 26.96 & 26.10 \\
\hline $\mathrm{FN}$ & 39.95 & 76.12 & NS & 68.33 & 7.41 & 68.93 & 15.11 \\
\hline FRIGA & 39.52 & 75.31 & NS & 79.90 & 19.05 & 25.96 & 33.16 \\
\hline GU & 57.38 & 109.35 & NS & 84.89 & 64.25 & 66.42 & 13.97 \\
\hline GX & 30.37 & 57.87 & INF & 69.87 & 0.00 & 38.62 & 12.97 \\
\hline H52 & 54.89 & 104.61 & NS & 84.21 & 44.44 & 30.50 & 60.42 \\
\hline HAR2 & 34.57 & 65.88 & NS & 73.33 & 11.64 & 52.00 & 1.32 \\
\hline HAR8 & 19.40 & 36.97 & INF & 51.67 & 6.52 & 7.18 & 12.24 \\
\hline IR & 31.83 & 60.66 & INF & 50.14 & 10.00 & 42.58 & 24.61 \\
\hline K 2528 & 37.77 & 71.98 & NS & 75.11 & 14.93 & 32.87 & 28.18 \\
\hline OA & 42.69 & 81.35 & NS & 78.60 & 40.74 & 12.78 & 38.64 \\
\hline PAZ2 & 22.70 & 43.26 & INF & 58.61 & 8.33 & 15.92 & 7.94 \\
\hline PSS2 & 36.62 & 69.79 & NS & 68.30 & 31.32 & 21.07 & 25.79 \\
\hline PSY4 & 53.86 & 102.64 & NS & 78.51 & 25.89 & 61.26 & 49.79 \\
\hline PUR2 & 51.30 & 97.79 & NS & 57.22 & 80.00 & 32.53 & 35.45 \\
\hline RHA266 & 58.94 & 112.31 & NS & 81.07 & 39.15 & 36.12 & 79.40 \\
\hline SD & 36.87 & 70.26 & NS & 85.32 & 9.62 & 33.82 & 18.72 \\
\hline SI & 31.95 & 60.89 & INF & 63.82 & 5.65 & 41.43 & 16.91 \\
\hline SL72 & 84.89 & 161.78 & SUP & 93.04 & 86.17 & 79.81 & 83.55 \\
\hline U 2169 & 24.64 & 46.96 & INF & 50.76 & 6.63 & 27.82 & 13.35 \\
\hline UCL 81 & 29.52 & 56.25 & INF & 73.89 & 1.79 & 22.83 & 19.55 \\
\hline WG(HA60) & 28.95 & 55.16 & INF & 63.48 & 6.67 & 19.44 & 26.19 \\
\hline WJR 1624 & 36.75 & 70.03 & NS & 64.73 & 10.00 & 46.19 & 26.08 \\
\hline WJR 1634 & 21.55 & 41.06 & INF & 49.98 & 2.08 & 30.02 & 4.10 \\
\hline WX & 38.20 & 72.79 & NS & 60.42 & 31.37 & 18.14 & 42.86 \\
\hline Location means & & & & 69.30 & 22.71 & 34.58 & 27.93 \\
\hline General mean: & $38.63 ;$ & =19.78; & & & & & \\
\hline
\end{tabular}


is thus possible to predict the reaction of hybrids from those of parental lines. One slight exception was that the two most resistant lines, IR and 90R18, gave hybrids better than expected from the parental lines.

Table 3: Percentage Downy mildew attack (race 710 ) on a factorial cross at INRA ClermontFerrand 2006. Means of 4 replications (check mean: $50.2 \%$ ).

\begin{tabular}{lccccccc}
\hline & IR & GX & FU & FRIGA & GU & SL72 & Mean M \\
\hline 90R18 & 7.6 & 33.8 & 21.2 & 41.8 & 42.2 & 66.0 & $35.4 \%$ \\
PR56 & 16.1 & 20.2 & 22.0 & 37.4 & 55.7 & 62.5 & $35.7 \%$ \\
PAZ2 & 25.2 & 37.6 & 40.2 & 29.2 & 72.0 & 46.4 & $41.8 \%$ \\
PUR2 & 20.5 & 38.7 & 51.3 & 39.9 & 76.7 & 60.7 & $48.0 \%$ \\
83HR4 & 28.8 & 46.8 & 39.5 & 57.5 & 81.0 & 71.1 & $54.1 \%$ \\
PSU7 & 31.8 & 61.1 & 65.5 & 83.8 & 77.1 & 91.4 & $68.5 \%$ \\
Mean F & $21.7 \%$ & $39.7 \%$ & $40.0 \%$ & $48.3 \%$ & $67.5 \%$ & $66.4 \%$ & $47.3 \%$ \\
\hline
\end{tabular}

Blocks $\mathrm{F}=2.11 \mathrm{~ns}$ Females $\mathrm{F}=43.35^{*}$ Interaction $\mathrm{F}=1.96 \mathrm{~ns}$

Hybrids $\mathrm{F}=10.80^{\star *}$ Males $\mathrm{F}=22.45^{\star *}$

Table 4: Percentage Downy mildew infection of the inbred lines, parents of the factorial cross, at INRA Clermont-Ferrand 2006. Means of 4 replications (check mean: 51.3\%).

\begin{tabular}{cccc}
\hline & Females & \multicolumn{2}{c}{ Males } \\
\hline IR & $27.9 \%$ & $90 R 18$ & $34.1 \%$ \\
GX & $30.9 \%$ & PR56 & $19.0 \%$ \\
FU & $28.3 \%$ & PAZ2 & $28.8 \%$ \\
FRIGA & $55.1 \%$ & PUR2 & $32.8 \%$ \\
GU & $96.2 \%$ & $83 \mathrm{HR} 4$ & $89.3 \%$ \\
SL72 & $76.8 \%$ & PSU7 & $77.3 \%$ \\
\hline
\end{tabular}

\section{DISCUSSION}

The results obtained since 2004 are encouraging since they indicate that useful levels of partial resistance exist in a wide range of agronomically valid cultivated sunflower genotypes and that inheritance is relatively simple. Either using the sources we have identified or from search among their own lines, breeders should be able to include partial resistance in future varieties.

The ease of use will depend on the results of two research programmes in progress. The first one is a QTL identification on 3 populations, one $\mathrm{F}_{3}$ and two RIL. These studies should provide not only markers (mostly SSR) but also answer the questions of:

- the number of QTLs involved,

- whether they differ according to genetic origin,

- whether they are related to Pl genes (Tourvieille et al., 2004, found no evidence for this). 
It should also open the field for research on candidate genes which would help to decide whether the resistance is truly of the non-race-specific type, and non $\mathrm{Pl}$ type genes giving wide-range but partial control of Downy mildew.

The main objective of the second programme in progress is to simplify the study of partial resistance by testing young plants in the growth chamber. It is essential to be able to carry out tests with a wide range of races, some of which must be kept in confinement chambers, to obtain evidence for non-race-specificity. It would also facilitate screening in areas where Downy mildew does not occur naturally and at any period during the year, not only when environmental conditions are favourable. It would also be an advantage if it were possible to distinguish partial resistance from segregation for $P l$ genes, since at present this is quite difficult.

How can this partial resistance to Downy mildew be used in breeding? It appears possible that partial resistance alone may be sufficient to avoid yield loss. The hybrid IR $\times 90$ R 18 only showed $7 \%$ attack when others had $80-90 \%$ of plants with Downy mildew symptoms and we have made the combination IR $\times$ OPB7 ( $16 \%$ attack when $90 \mathrm{R} 18$ had $34 \%$ ), which will be observed in trials in 2007. Large-scale testing will be necessary to draw a definite conclusion on this point. Probably the first method to include partial resistance in new varieties will be to combine $P l$ genes in one parent with good partial resistance in the other. This should at least provide protection against very rapid development of a new race. To develop new inbred lines with good partial resistance, with or without $\mathrm{Pl}$ genes, will require molecular markers, basically to identify plants carrying the required QTL, but they would also be useful for $P l$ genes when the reaction of these to seedling tests is difficult to distinguish from good partial resistance.

A good deal of research remains to be done to obtain sunflower varieties with durable resistance to Downy mildew, but the first, most important step is for breeders, seed merchants and farmers to understand the importance of this character. The evidence suggests that pathologists, geneticists and breeders will be able to develop techniques necessary for its inclusion in high-yielding sunflowers.

\section{ACKNOWLEDGEMENTS}

We would like to thank the personnel of the INRA farm at ClermontFerrand for their help in the trials. Promosol provided financial support for this programme, which was made with the support and collaboration of CETIOM, Caussade, Maïsadour, Monsanto, Pioneer, R.A.G.T., Soltis and Syngenta.

\section{REFERENCES}

Bert, P-F., Tourvieille de Labrouhe, D., Philippon, J., Mouzeyar, S., Jouan, I., Nicolas, P., Vear, F., 2001. Identification of a second linkage group carrying genes controlling resistance 
to Downy mildew (Plasmopara halstedii) in sunflower (Helianthus annuus L.). Theor.Appl.Genet. 103:992-997

Bouzidi, M.F., Badaoui, S., Cambon, F., Vear, F., Tourvieille de Labrouhe, D., Nicolas, P., Mouzeyar, M., 2001. Molecular analysis of a locus for resistance to Downy mildew in sunflower with specific PCR-based markers. Theor. Appl. Genet. 104:592-600.

Moinard, J., Mestries, E., Penaud, A., Pinochet, X., Tourvielle de Labrouhe, D., Vear, F., Tardin, M.C., Pauchet, I., Eychenne, N., 2006. Le mildiou du tournesol. Phytoma "La défence des végétaux" 589:33-43.

Mouzeyar, S., Drevet-Roeckel, P., Phillipon, J., Gentzbittel, L., Vear, F., Tourvieille de Labrouhe, D. and Nicolas P., 1995. RFLP and RAPD mapping of the sunflower Pl1 gene for résistance to Plasmopara halstedii race 1. Theor.Appl.Genet. 91:733-737.

Radwan, O, Bouzidi M-F., Vear F., Phillipon J., Tourvieille de Labrouhe D., Nicolas P., Mouzeyar S., 2002. Identification of non-TIR-NBS-LRR markers linked to the Pl5/Pl8 locus for resistance to Downy mildew in sunflower. Theor.Appl.Genet. 106:1438-1446.

Tourvielle, D., 2004. Faire durer la résistance au mildiou. Rencontres Annuelles du CETIOM. Paris (France). 30/11-1/12/2004:67-73.

Tourvieille de Labrouhe, D., Serre, F., Walser, P., Philippon, J., Vear, F., Tardin, M.C., Andre, T., Castellanet, P., Chatre, S., Costes, M., Ćuk, L., Jouve, P., Madeuf, J.L., Mezzarobba, A., Plegades, J., Pauche,t I., Mestries, E., Penaud, A., Pinochet, X., Serieys, H., Griveau, Y., Moinard, J., 2004. Partial, non-race specific resistance to Downy mildew in cultivated sunflower lines. Proc. $16^{\text {th }}$ Int. Sunflower Conf., Fargo, USA. 1:105-110.

Vear, F., 2004. Breeding for durable resistance to the main diseases of sunflower. Proc. $16^{\text {th }}$ Int. Sunflower Conf. Fargo, ND, USA. Plenary Session 1:15-28.

Vear, F., Willefert, D., Walser, P., Serre, F., Tourvieille de Labrouhe, D., 2004. Reaction of sunflower lines to a series of Sclerotinia sclerotiorum isolates. Proc. $16^{\text {th }}$ Int. Sunflower Conf., Fargo, USA. 1:135-140.

\title{
RECIENTES INVESTIGACIONES DE RESISTENCIA A TIZÓN, ÚTIL PARA LA SELECCIÓN DE GIRASOL DESTINADO A LOS FINES INDUSTRIALES
}

\author{
RESUMEN
}

Para que girasol sea un cultivo lucrativo para la utilización en los fines industriales, las inversiones en su producción tienen que ser lo más bajas posible. La resistencia genética es una base significante para la eliminación de las enfermedades sin pulverización o tratamiento de la semilla. En Francia, el Tizón es una de las enfermedades potencialmente más importantes. Hasta ahora, en las investigaciones se han utilizado con éxito todos los genes de resistencia principales (genes $\mathrm{Pl}$ ), pero, con la presentación de siete razas nuevas desde el año 2000 , se ha pasado en investigaciones de la resistencia más duradera. A partir del año 2003, se han formado los nuevos métodos de los ensayos de campo de investigación de la resistencia al ataque del Tizón en los genotipos que carecen de genes $P l$ que protejan eficazmente de las razas de enfermedades actualmente dominantes. Se ha demostrado que en las líneas del girasol cultivado existe un nivel significante de la resistencia parcial (la infeccin de $15 \%$ cuando el material sensible demuestra la infección de 80 90\%). Aparentemente, esta resistencia es independiente de la raza (por lo menos de las razas 710 y 703). La herencia está bajo el control aditivo, y el comportamiento del híbrido puede preverse muy bien sobre la base de las líneas consanguíneas. En el trabajo se consideran el programa de investigación actual y el programa de investigación futuro, y se dan sugerencias relacionadas con la utilización de la resistencia parcial en los programas de selección. 


\title{
NOUVELLE RECHERCHE SUR LA RÉSISTANCE AU MILDIOU POUVANT SERVIR À LA SÉLECTION DU TOURNESOL DESTINÉ À UN USAGE INDUSTRIEL
}

\author{
RÉSUMÉ
}

Pour que le tournesol devienne une culture profitable pour l'industrie l'investissement dans la production doit tre aussi bas que possible. La résistance génétique est donc essentielle pour contrôler les maladies sans avoir recours à la vaporisation ou au traitement de la graine. En France, le mildiou est l'une des maladies potentielles les plus importantes. Jusqu'à maintenant tous les gènes de résistances principaux ont été utilisés avec succès (gènes $P l$ ) mais avec l'apparition de sept nouvelles races depuis 2000, des recherches sur une résistance plus durable ont été entreprises. Depuis 2003, dans les expériences sur le terrain, de nouvelles méthodes ont été créées qui portent sur la résistance aux attaques de mildiou sur les génotypes qui ne possèdent pas les gènes $P l$ qui les protègeraient efficacement contre les races de maladie dominantes actuellement. Il a étédémontré qu'il existait dans les lignes de tournesol cultivé un niveau important de résistance relative (infection de $15 \%$ quand le matériel sensible montre une infection de $80-90 \%$ ). Il semble que cette résistance soit indépendante de la race (au moins des races 710 et 703). L'hérédité est sous contrôle additif et le comportement des hybrides peut très bien être prévu à partir des souches pures. Cet article étudie les programmes actuel et futur et donne des suggestions pour l'utilisation de la résistance relative dans les programmes de sélection. 